\title{
First steps towards national radon action plan in Serbia
}

\author{
Vladimir Udovičić, \\ Dimitrije Maletić, \\ Maja Eremić Savković, \\ Gordana Pantelić, \\ Predrag Ujić, \\ Igor Celiković, \\ Sofija Forkapić, \\ Dragoslav Nikezić, \\ Vladimir M. Marković, \\ Vesna Arsić, \\ Jovana Ilić
}

\begin{abstract}
Radon problem has a special attention in many countries in the world and the most of them have established national radon programmes. The radon issues in Serbia have not been approached in a systematic and organized way. Currently, there are many research groups and institutions working in radon field, and it is a good basis to integrate all these activities into a comprehensive national programme to define the strategic objectives and action plan for the next few years. Also, Serbia as a candidate for membership in the EU is obliged to harmonize its legislation, including the field of radiation protection in which the radon issues has an important role. In this report, a brief history of radon research, present status and plans for the future activity on radon issues in Serbia are presented. Regarding the long-term plans, the establishment and implementation of the Radon Action Plan with the primary goal of raising awareness about the harmful effects of public exposure to radon and implementing a set of measures for its reduction. In that sense, the synergy between the national, regional and local organizations responsible for public health and radiation protection must be achieved.
\end{abstract}

Key words: radon $\bullet$ action plan $\bullet$ survey

V. Udovičić ${ }^{\bowtie}$, D. Maletić

Institute of Physics Belgrade,

University of Belgrade,

118 Pregrevica Str., 11080 Belgrade, Serbia,

E-mail: udovicic@ipb.ac.rs

\section{Eremić Savković}

Serbian Radiation Protection and Nuclear Safety Agency, Belgrade, Serbia

G. Pantelić, P. Ujić, I. Čeliković

Vinča Institute of Nuclear Sciences,

University of Belgrade,

Belgrade, Serbia

S. Forkapić

Department of Physics,

Faculty of Science,

University of Novi Sad,

Novi Sad, Serbia

D. Nikezić, V. M. Marković

Faculty of Science,

University of Kragujevac,

Kragujevac, Serbia

V. Arsić, J. Ilić

Serbian Institute of Occupational Health

"Dr Dragomir Karajović",

Belgrade, Serbia

Received: 4 January 2016

Accepted: 31 March 2016

\section{Introduction}

Radon is a noble, naturally occurring radioactive gas. Radon contribute to almost $50 \%$ of the overall high-effective annual dose to the population received from all sources of natural radioactivity. Harmful effects of radon has been proven in a large number of epidemiological studies [1]. The latest recommendation of the International Atomic Energy Agency (IAEA) [2] and Directive EC [3] relating to the field of radiation protection, radon problem got more space and importance because the World Health Organization (WHO) has identified radon as the second biggest cause of cancer lung [4]. In addition, radon is included in the ranks of major pollutants of indoor air [5]. Current knowledge about the mechanisms by which radon is harmful to human health are reflected primarily in harmful, radioactive radon progeny fact. In fact, radon progenies are attached to the aerosol particles from the air and such radioactive particles enter the body through inhalation. These radioactive aerosols deposited in the lungs emit alpha radiation. The harmful activity can be seen in disorders of the cellular structure of DNA, causing the development of cancer cells. Consequently, radon problem has been addressed seriously, and in a number of countries, national radon programme is established, which is basically a multidisciplinary nature and requires the involve- 
ment of a large number of experts, researchers involved in radiation physics, geo sciences, chemistry, biology to specialist in various fields of medicine. In that sense, the group of radon professionals decide to start working on establishing and developing national radon programme in Serbia. In this paper, a brief history of radon research, present status and plans for the future activity on radon issues in Serbia are presented.

\section{International framework}

The regulations related to the exposure of the population to radon and its progenies are different worldwide. Based on the researches and a large number of epidemiological studies done in the recent past, the new standards and recommendations have to be incorporated into the national legislation regarding radon issues. Basically, a new approach to the radon issue is to introduce the concept of the reference level (not as strict boundaries between safe and dangerous concentrations of radon, but the annual average indoor radon concentration above which it is necessary to take measures to reduce radon). It differs from action level (the radon concentration above which, if it is found that the measured concentration is greater than defined, gives recommendations to take measures for its reduction). The new concept is incorporated in two new documents. One is developed at the International Atomic Energy Agency (IAEA) [2]. In this new BSS (international Basic Safety Standards), radon is placed in several topics, but the most important is requirements of 50 (Requirement 50: Public exposure because of radon indoors). It defines the reference level, in dwellings of high occupational factors, which must not exceed $300 \mathrm{~Bq} \cdot \mathrm{m}^{-3}$. Assuming equilibrium factor for radon 0.4 and the annual occupational factors of $7000 \mathrm{~h}$, the reference level of $300 \mathrm{~Bq} \cdot \mathrm{m}^{-3}$ corresponds to an annual effective dose of $10 \mathrm{mSv}$, with dose conversion factor (DCF) of $7.5 \mathrm{mSv}$ per WLM (working level month). The request 52 (Requirement 52: Exposure in workplaces) defines the reference level for radon in workplaces of $1000 \mathrm{~Bq} \cdot \mathrm{m}^{-3}$. As the occupation factor for $2000 \mathrm{~h}$ with the same factor to balance radon of 0.4 leads to the same effective annual dose of $10 \mathrm{mSv}$. Important conclusions are based on the collected data and performed radon risk maps, the country has to decide and implement adequate control of the indoor radon, to inform the public and other stakeholders and, finally, to establish and implement Radon Action Plan (RAP).

The second document is EU Directive 2013/59 [3]. In the article 74: Indoor exposure to radon, writes the similar as in the new BSS, accept that the reference level shall not exceed $300 \mathrm{~Bq} \cdot \mathrm{m}^{-3}$ for the all indoor environment, living and workplaces. Article 103 defines RAP to be developing in member states: The action plan shall take into account the issues set out in Annex XVIII and be updated on a regular basis. Annex XVIII defined 14 items to consider in preparing the national RAP. In the case of Serbia, the first steps towards RAP are described in the next section.

\section{National radon action plan in Serbia}

Serbia did not have a systematic approach to the radon problem. In this sense, there were individual initiatives and research activities dealing with radon:

University of Novi Sad, Faculty of Science, Department of Physics, Chair of Nuclear Physics, Novi Sad

Radon mapping of Autonomous Province of Vojvodina [6], long-term and short-term measurements of radon concentration in soil, water and air using passive devices, active device RAD7, exhalation and diffusion measurements [7], charcoal canisters with gamma spectrometric analysis [8].

\section{University of Belgrade, Vinča Institute of Nuclear Sciences, ECE Lab Belgrade}

\section{Department for Nuclear and Plasma Physics}

Mapping radon and thoron throughout south-eastern Serbia, Kosovo and Metohija parts of western Serbia $[9,10]$ by using different passive devices; electrochemical etch track detectors in a specially designed and built in laboratory [11]; developing method for radon and thoron exhalation from building material [12]; radon measurement campaigns in the schools and houses in the Sokobanja municipality [13].

\section{Radiation and Environmental Protection Depart- ment}

Active charcoal detectors are used for testing the concentration of radon in dwellings. The method of measurement is based on radon adsorption on coal and measurement of gamma radiation of radon daughters according to US EPA protocol. Based on this EPA procedure and national and international intercomparison, the laboratory developed a set of procedures for charcoal detector exposure and measurement $[14,15]$.

\section{University of Belgrade, Institute of Physics Belgrade,} Low-Background Laboratory for Nuclear Physics

Radon monitoring in the underground low-background laboratory with the passive and active devices [16]; radon laboratory for chemical etching of the track detectors and automatic counting of the tracks by optical microscopy [17]; modelling of the indoor radon behaviour [18].

\section{Institute of Occupational Health of Serbia "Dr Dragomir Karajović", Center for Radiological Protection, Belgrade}

Radon measurements using charcoal canisters with gamma spectrometric analysis, radon monitoring in 
schools and kindergartens in the city of Belgrade from 1991 [19] and radon measurements campaigns in schools and kindergartens in Belgrade from 2010 [20].

\section{University of Kragujevac, Faculty of Science Kragujevac, Institute of Physics}

Radon measurement using passive devices with chemical treatment of the track detectors and automatic scanning of the developed detectors; modelling of the behaviour of indoor radon [21]; dosimetric modelling of the effects of the inhalation of radon and its progeny in the lung [22].

Based on the great experience of research related to radon, the group of radon professionals organized Radon Forum in May 2014 and made a decision to start work on RAP in Serbia. The responsibility for the establishment and implementation of RAP is on national regulatory body: Serbian Radiation Protection and Nuclear Safety Agency (SRPNA). We started with Internet radon forum (www.cosmic.ipb. ac.rs/radon_forum), which provides an opportunity for radon professionals in Serbia to meet and discuss radon activities and plans. Also, SRPNA formed a 'radon working group' that will manage RAP. The organization chart of the institutions involved in RAP is shown in Fig. 1.

Short-term plans (to the end of 2015) include

- carrying out initial representative national indoor radon survey for this purpose,

- developing communication strategy (first basic information leaflet on radon to accompany the measurement explaining the purpose of the measurement, Internet site: http://cosmic.ipb.ac.rs/ radon/index.html; public relation; etc.).

\section{First national indoor radon survey in Serbia}

As a first step in RAP, it is the national radon survey in Serbia planned to be done in 2015. In the cooperation with IAEA, SRPNA through radon working group made the design of the first national radon survey in Serbia. It is well known that regarding the objective of the indoor radon survey, there are two types of survey:

- population-weighted survey by measuring indoor radon levels in randomly selected homes (to estimate the distribution of radon public exposures),

- geographically based survey where homes are randomly selected to obtain a minimum density of measurements per area unit chosen, e.g., a grid square, an administrative unit (to identify radon prone areas, radon map).

Every radon survey needs to check the representativeness (e.g. compare certain parameters in the actual sample with corresponding values in the last census). A carefully designed survey can, in principle, meet the requirements and objectives of both the types of surveys. In the case of Serbia, we choose a stratified (target population is partitioned into separated groups - STRATA) sampling design. We defined STRATA according to the administrative divisions of Serbia into districts.

In principle, our design model can be described as follows:

- SRPNA, in cooperation with the IAEA through the national project SRB9003 - Enhancing the Regulatory Infrastructure and Legislative System,

- Expert mission on National Radon Trial Survey and Raising Awareness of Key Stakeholders held in SRPNA, Belgrade, 2-4 February 2015,

- Equipment: Leasing of 6000 track-etched indoor radon detectors; the distribution of detectors across the Serbian territory should be the responsibility of SRPNA,

and relevant ministries began with the national programme for indoor radon measurements in dwellings and flats in Serbia. The aim of this programme is to determine the radiological exposure risk to radon in residential areas because of the inhalation of this gas as well as to locate areas in Serbia with high concentrations, areas with high radon potential. Within the working group on radon, the division of

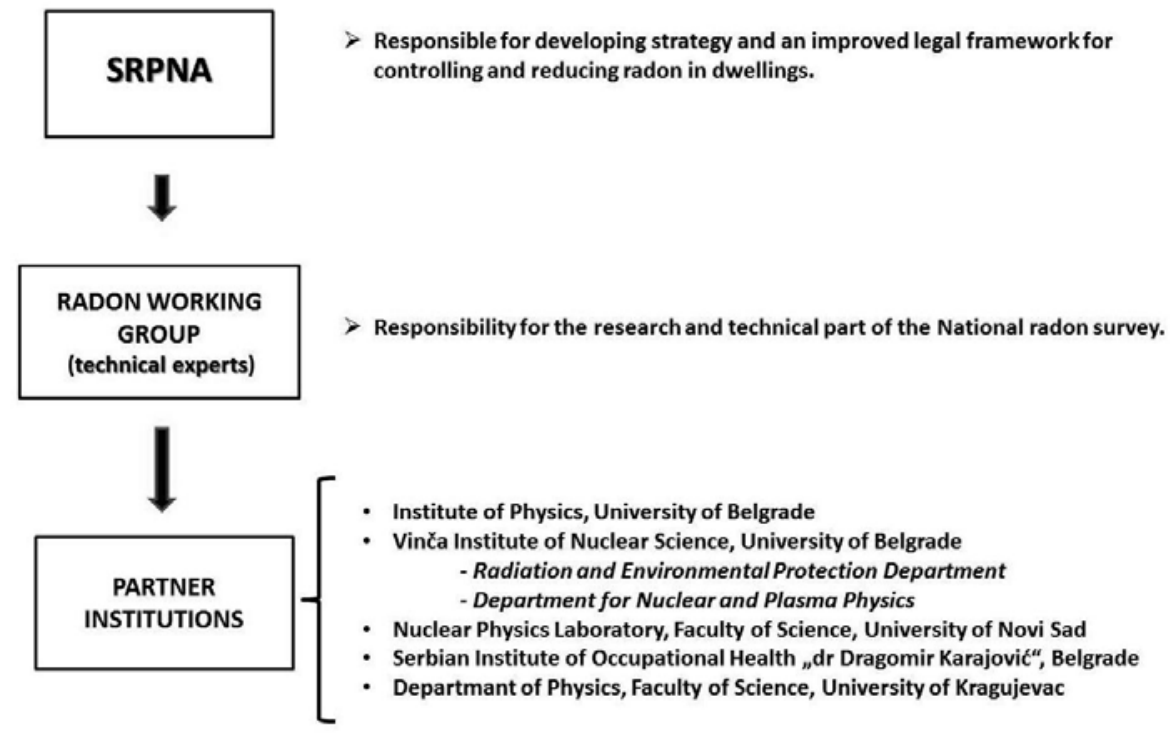

Fig. 1. Organization chart of the institutions involved in RAP. 
responsibilities of individual institutions in a given set of administrative regions was established. All owners of houses and apartments (who wish to participate in the project), with the aim of determining the concentration of radon, filled predefined questionnaire on the Web site dedicated to radon in Serbia (http://cosmic.ipb.ac.rs/radon/index.html). In this way, they expressed interest to participate in the project. In total, 6000 detectors have been distributed during October 2015 and will be exposed in houses and apartments for six months (till April 2016). Afterwards, the detectors will be sent to an authorized laboratory to be processed, and consequently, we should get data for the first national map radon risk in Serbia. The measurement results will be presented to the owners of houses and apartments that are used for the measurement. Based on these results, in cases where radon concentration exceeds current intervention level of $200 \mathrm{~Bq} \cdot \mathrm{m}^{-3}$ for new developments or $400 \mathrm{~Bq} \cdot \mathrm{m}^{-3}$ for existing facilities, the whole set of measures that could result in a reduction of the radon concentrations and thus reduce the risk of getting lung cancer will be recommended. Additionally, all data collected for the whole of Serbia will enable the determination of the national reference level for radon. During the realization of the national programme for indoor radon measurements, we plan to perform communication strategy (first basic information leaflet on radon to accompany the measurement explaining the purpose of the measurement, internet site, public relation, public education, etc.).

\section{Conclusions}

World Health Organization declared radon as the second most important cause of getting lung cancer. Radon problem being addressed seriously, and in a number of countries, there are established national radon programme. Serbia started work on RAP in 2014, with the first step of preparing, and performed the national indoor radon survey in Serbia, planned to be done in 2015. The responsibility for the establishment and implementation of RAP is on national regulatory body: Serbian Radiation Protection and Nuclear Safety Agency. The results of national radon survey serves to evaluate the existing exposure situation and to define the next steps in establishing and developing RAP in Serbia. Also, the Serbian experience in efforts to have systematic approach to the radon issues, described in this paper, may be useful to the other countries who wish to establish their own RAP.

\section{References}

1. Darby, S., Hill, D., Auvinen, A., Barros-Dios, J. M., Baysson, H., Bochicchio, F., Deo, H., Falk, R., Forastiere, F., Hakama, M., Heid, I., Kreienbrock, L., Kreuzer, M., Lagarde, F., Mäkeläinen, I., Muirhead, C., Oberaigner, W., Pershagen, G., Ruano-Ravina, A., Ruosteenoja, E., Schaffrath Rosario, A., Tirmarche,
M., Tomáscaronek, L., Whitley, E., Wichmann, H. -E., \& Doll, R. (2005). Radon in homes and risk of lung cancer: collaborative analysis of individual data from 13 European case-control studies. Brit. Med. J., 330, 223-227.

2. International Atomic Energy Agency. (2011). Radiation protection and safety of radiation sources: International basic safety standards Interim edition. General safety requirements Part 3. Vienna: IAEA. Retrieved from http://www-pub.iaea.org/MTCD/ publications/PDF/p1531interim_web.pdf.

3. Council of the European Union. (2014). Council Directive 2013/59/EURATOM of 5 December 2013 laying down basic safety standards for protection against the dangers arising from exposure to ionising radiation, and repealing Directives 89/618/Euratom, 90/641/Euratom, 96/29/Euratom, 97/43/Euratom and 2003/122/Euratom. (Official Journal of the European Union 2014; L13). Retrieved from http://www. srbatom.gov.rs/srbatom/doc/eu-direktive/2013\%20 59\%20eng.pdf.

4. World Health Organization. (2009). WHO handbook on indoor radon: a public health perspective. Retrieved from http://www.who.int/ionizing_radiation/ env/radon/en/index1.html.

5. World Health Organization. (2010). WHO guidelines for indoor air quality: selected pollutants. Retrieved from http://www.who.int/indoorair/publications/9789289002134/en/index.html.

6. Forkapić, S., Bikit, I., Slivka, J., Čonkić, Lj., Vesković, M., Todorović, N., Varga, E., Mrđa, D., \& Hulber, E. (2006). Indoor radon in rural dwellings of the South-Pannonian region. Radiat. Prot. Dosim., 123(3), 378-383.

7. Nikolov, J., Todorovic, N., Bikit, I., Petrovic Pantic, T., Forkapic, S., Mrda, D., \& Bikit, K. (2014). Radon in thermal waters in South-East part of Serbia. Radiat. Prot. Dosim., 160(1/3), 239-243.

8. Todorović, N., Bikit, I., Vesković, M., Krmar, M., Mrda, D., Forkapić, S., Hansman, J., Nikolov, J., \& Bikit, K. (2014). Radioactivity in the indoor building environment in Serbia. Radiat. Prot. Dosim., 158(2), 208-215.

9. Žunić, Z. S., Yarmoshenko, I. V., Veselinović, N., Zhukovsky, M. V., Ujić, P., Čeliković, I., Mc Laughlin, J. P., Simopoulos, S. E., Birovljev, A., Fujimoto, K., Paridaens, J., Trotti, F., Tokonami, S., Olko, P., Kozak, K., Bochicchio, F., Ramola, R., Mietelski, J. W., Jakupi, B., Milić, G., Ciotoli, G., Kelleher, K., Budzanowski, M., Sahoo, S. K., Vanmarcke, H., \& Waligorski, M. P. R. (2009). Identification and assessment of elevated exposure to natural radiation in Balkan region (Serbia). Radioprotection, 44, 919-925.

10. Žunić, Z. S., Janik, M., Tokonami, S., Veselinović, N., Yarmoshenko, I. V., Zhukovsky, M., Ishikawa, T., Ramola, R. C., Ciotoli, G., Jovanović, P., Kozak, K., Mazur, J., Celiković, I., Ujić, P., Onischenko, A., Sahoo, S. K., \& Bochicchio, F. (2009). Field experience with soil gas mapping using Japanese passive radon/ thoron discriminative detectors for comparing high and low radiation areas in Serbia (Balkan region). $J$. Radiat. Res., 50(4), 355-361.

11. Zunic, Z. S., Ujić, P., Nađđerđ, L., Yarmoshenko, I. V., Radanović, S. B., Komatina Petrović, S., Čeliković, I., Komatina, M., \& Bossew, P. (2014). High variability of indoor radon concentrations in uraniferous bedrock areas in the Balkan region. Appl. Radiat. Isot., 94, 328-337.

12. Ujic, P., Č́eliković, I., Kandić, A., \& Žunić, Z. (2008). Development of method for radon/thoron exhalation measurement. Radiat. Meas., 43(8), 1396-1401. 
13. Bochicchio, F., Žunić, Z. S., Carpentieri, C., Antignani, S., Venoso, G., Carelli, V., Cordedda, C., Veselinović, N., Tollefsen, T., \& Bossew, P. (2014). Radon in indoor air of primary schools: a systematic survey to evaluate factors affecting radon concentration levels and their variability. Indoor Air, 24, 315-326.

14. Pantelić, G., Živanović, M., Eremić Savković, M., \& Forkapić, S. (2013). Radon concentration intercomparison in Serbia. In Ž. Knežević, M. Majer, \& I. Krajcar-Bronić (Eds.), Proceedings of the Ninth Symposium of the Croatian Radiation Protection Association, 10-12. April 2013, Krk, Croatia (pp. 193-198). Zagreb: CRPA.

15. Pantelić, G., Eremić Savković, M., Živanović, M., Nikolić, J., Rajačić, M., \& Todorović, D. (2014). Uncertainty evaluation in radon concentration measurement using charcoal canister. Appl. Radiat. Isot., $87,452-455$.

16. Udovičić, V., Aničin, I., Joković, D., Dragić, A., Banjanac, R., Grabež, B., \& Veselinović, N. (2011). Radon time-series analysis in the Underground Low-Level Laboratory in Belgrade, Serbia. Radiat. Prot. Dosim., 145(2/3), 155-158.

17. Banjanac, R., Dragić, A., Grabež, B., Joković, D., Markushev, D., Panić, B., Udovičić, V., \& Aničin, I. (2006). Indoor radon measurements by nuclear track detectors: Applications in secondary schools. Facta Universitatis, 4, 93-100.
18. Maletić, D., Udovičić, V., Banjanac, R., Joković, D., Dragić, A., Veselinović, N., \& Filipović, J. (2014). Comparison of multivariate classification and regression methods for indoor radon measurements. Nucl. Technol. Radiat. Prot., 29, 17-23.

19. Eremić-Savković, M., Pantelić, G., Tanasković, I., Vuletić, V., \& Javorina, Lj. (2002). Concentration of radon in apartments on the territory of Belgrade in period 1997-2001. Arch. Toxicol. Kinet. Xenobiot. Metab., 10(1/2), 195-197.

20. Arsić, V., Ilić, J., Bogojević, S., Tanasković, I., Eremić-Savković, M., \& Javorina, Lj. (2014). Assessment of the effective radon dose, measured in schools and kindergartens in Belgrade during 2012 and 2013. In Proceedings of Second East European Radon Symposium (SEERAS), May 27-30, 2014, Niš, Serbia (pp. 17-20).

21. Stevanovic, N., Markovic, V., \& Nikezic, D. (2010). Relationship between deposition and attachment rates in Jacobi room model. J. Environ. Radioact., 101(5), 349-352.

22. Jovanovic, B., Nikezic, D., \& Stevanovic, N. (2011). Applied mathematical modeling for calculating the probability of the cell killing per hit in the human lung. J. Radioanal. Nucl. Chem., 290(3), 607-613. 